\title{
Significant Factors of Delay in Construction Projects in Afghanistan
}

\author{
Sayed Behbood Hosaini, Sandeep Singla
}

\begin{abstract}
This research investigates the factors, which cause delay in construction projects in Afghanistan. Delay is one of the major challenges during the implementation of the construction projects, and it is the late completion of the activities or works of a project compared to the planned. A large number of construction projects in Afghanistan are facing delay during the implementation. Project delay negatively affects the prestige and dignity of the government organizations and in general, failures and weaknesses of the projects created distance between the people and the government and shows incapacity of the Government in the implementation of the projects all around the country in Afghanistan. Several similar studies from developing countries have been reviewed and a survey has been conducted for data collection from the different public organizations of Afghanistan. The analysis of the collected data points out the significant causes of delay in construction project in Afghanistan as; ineffective planning and scheduling of a project by contractor, delay in progress payments by client, poor site management and supervision of contractors by consultant and client, financial difficulties by contractor, insufficient controlling and monitoring by consultant and client, non-availability of experienced technical staff of contractor, late in reviewing and approving design documents by client, lack of communication and coordination between the parties, delay in delivery of materials to site, inadequate contractor experience, political influences and warlords intervention. Finally, this thesis provides applicable recommendations to minimize or eliminate the causes of delay in construction projects in Afghanistan.
\end{abstract}

Keywords: significant factors, delay, construction projects, Afghanistan

\section{INTRODUCTION}

\section{Background}

Afghanistan is a country, which has been a battlefield for almost 4 decades. During the war the entire infrastructure in the country was destroyed and the people deprived of the basic needs of life such as, water sanitation, education, shelter, electricity, and health, etcetera.

In 2001 after the collapse of the Taliban administration, Afghanistan has been approached to the attention of the world community with two objectives; first, the world community including the United States of America and its allies made a commitment to abolish the insurgencies from the country, and the second intention was to help Afghanistan to improve and develop its infrastructure in different sectors. [1] Donor countries helped Afghanistan to construct development projects all over the country to improve the living quality of the people, but due to some obvious and hidden challenges during the last 15 years, most of the projects have failed to be completed on schedule. Failure of the projects negatively affects the donors' contribution to construction projects of Afghanistan.

Revised Manuscript Received on June 15, 2019

Sayed Behbood Hosaini, Sandeep Singla, RIMT University, Punjab, India
In 2011 Afghanistan was ranked as 172 out of 187 countries on the UNDP's Human Development Index, and is one of the world's poorest countries in the world. [2]

Since the establishment of the new government in Afghanistan in 2001, most of the ministries are facing challenges during the implementation of development projects in all over the country, therefore they are unable to spend more than $50 \%$ of its development budget annually. It explains that implementation of the development projects is facing challenges that is why the budget expenditure is below 50 percent. There are two types of budget in the government of Afghanistan, Development Budget and Operational Budget. [3]

Development Budget: Is the second largest portion of the government budget, which is being used for the implementation of the development projects all over the country in Afghanistan.

Operational Budget: Is the largest portion of the government budget that is used for the government expenditure and salaries of the officials (etc.) in the country. according to the Fiscal budget expenditure sheet of the Ministry of Finance in Afghanistan, in last 15 years most of the public organizations of the government could not spend more the $50 \%$ of their development budget due to several reasons and factors, and mainly due to the problems in the construction phase of the projects' implementation.

Afghanistan is a country, which has been dependent on donors' aids since the collapse of the Taliban regime in 2001. Meanwhile USD 100 Billion has been spent for development purposes by the donor countries. According to the reports from the Ministry of Finance of Afghanistan almost $22 \%$ of the assisted capital was spent through government channels and the rest (78\%) was spent through the donor countries. The money was not spent efficiently, most of the projects were not well implemented or failed, and that is why it could not make significant changes to the people's life in the country. There are several challenges that are commonly faced during projects implementation in Afghanistan. Some of the most obvious challenges are insecurity, corruption, poor qualification of the contractor's technical staff, payment delays by clients, and poor site management and supervision by client and contractor, as well as some hidden challenges.

Due to the lack of capacity and necessary equipment and machinery the government organizations are unable to implement the projects by themselves. In principle, implementations of the development projects are the responsibility of the designated government authority. Hiring 
contractors is the easiest way to implement the projects, rather than training the officials for and preparing the facilities to implement the projects by themselves.

Unfortunately, due to many reasons, in Afghanistan a large number of construction projects fail to meet their original contract deadlines.

This research investigates to find the significant causes of delay in construction projects of Afghanistan and explores and provides recommendations to decrease the impact of delays on construction projects in Afghanistan.

\section{Problem Statement:}

A huge number of Public Construction projects in Afghanistan are not implemented on time due to several factors. Majid (2006) demonstrates that a construction project is commonly acknowledged successful when it is completed on time, within budget and accordance to the specifications and satisfaction of the project stakeholders (Client, Consultant, and Contractor).

In Afghanistan a large number of construction projects are unsuccessful, because the projects are not completed on time, so the construction projects fail to meet its contract deadline and it negatively impacts the development process of the country.

\section{Purpose of this research:}

For achieving the purpose of this research, the following objectives need to be developed:

1. To find the cause of delay in construction Projects in Afghanistan.

2. To distinguish the significant factors that causes delay in construction projects in Afghanistan (Top ten Factors).

3. To find out how developing and developed nations handled these challenges through literatures review.

4. To propose applicable solution to avoid delay in construction projects in Afghanistan.

\section{LITERATURE REVIEW}

\section{Project management Challenges in Afghanistan}

Afghanistan is a country, which has remained dependent on donors' aids, and since 2001 more than USD 100 Billion has been spent for development purposes in the country. For reconstruction purposes, donor countries aimed to implement the infrastructure projects, but projects have faced challenges during implementation. There are several challenges that are commonly faced by construction projects during project implementation in Afghanistan. However, insecurity is one of the main challenges against implementation of development projects all over the country. In this regard, there are several observations form the people involved in project management professions in Afghanistan. [4]

\section{Logistic, Security and Capacity}

In 2010 a question was asked to Mr. David who has been involved in project management in Africa, Europe, South America, the Caribbean, and central Asia and he is currently working in Afghanistan, providing oversight support for infrastructure projects funded by the United States government that, (What major challenges have you observed with completing construction projects in Afghanistan?). He responded that there are mainly 3 challenges during the implementation of the construction projects in Afghanistan; these problems are generally categorized as logistics, security and capacity. [5]

\section{Logistics and security}

Based on the location of a project, security could be a huge expense, usually in the range of 5 to 15 percent of the total project cost (David, 2010). [5]

Logistics and security are closely related to each other. delays at the border due to security or custom clearance issues causes the cost of the project to increase. Custom problems with neighboring countries due to political issues and corruption in the government could be another big challenge. Sometimes assaults on projects are not only performed by the Taliban or insurgent elements but also can be triggered by disgruntled employees or terminated subcontractors. David observed that a contractor's relationship with the local community is sometimes a more important part of security planning than the number of armed guards employed. If local residents are hired to work on a project, they tend to help protect it.

\section{Capacity}

In 2010, David observed that the local and domestic construction firms in Afghanistan suffers from a lack of capacity, causing in project quality issues and delays. Local contractors benefit from an international donor emphasis to hire Afghanistan domestic contractors for implementation of the construction projects, but in many cases, they are not able to deliver on contracts because of their inability and incapacity to find skilled workers and managers. Local contractors mainly suffer from lack of capacity in design and construction management, so they cannot deliver projects based on the methods utilized by donors. There are several capacity development programs held by the international community to help address these issues, However, the construction industry needs much more time and more capacity building programs to strengthen the construction firms for better and effective services delivery.[5]

\section{The Key Challenges of Development Projects in} Afghanistan

Sadeqi (2014) demonstrated the main challenges of development projects in Afghanistan as the following factors: [6]

1. Projects are mainly contracted outside of Afghanistan and there is no close monitoring by the Afghanistan government authorities.

2. In past 10 years internal and external non-governmental organizations (NGOs) were

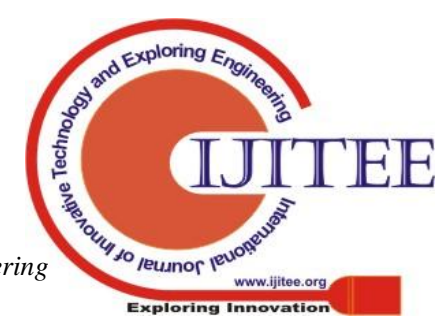


the biggest project implementers in the country. All the government organizations implemented the development projects through these NGOs.

3. NGOs were passing or selling projects to another NGO and subcontractors; which led to fewer funds to be used and finally leading to a very low-quality work.

4. Due to the lack of capacity and necessary equipment and machinery, the government organizations are unable to implement the projects by themselves.

In principle, the implementation of development projects is the responsibility of the designated government authority in the country; Hiring contractors is the easiest way to implement the projects, rather than training the officials for and preparing the facilities to implement the projects by themselves.

5. In the past years, unfortunately there was not proper monitoring of these NGOs, while they are implementing the projects.

Additionally, former Minister of MRRD (Barmak, 2013) deliberated the main challenges of national solidarity projects in Afghanistan through a radio and television channel, which was later on published on the Internet, pointed out the following factors as the main challenges of projects failure in Afghanistan: [7]

- Insecurity

- Intervention of the local leaders to hinder the projects implementation

- Low capacity of the Afghan contractors

\section{Internal and External Factors}

Nushin (2012) indicates two major factors that are causing projects failure in Afghanistan as internal and external factors. [8]

\section{Internal factors}

The following factors as the internal factors negatively contributed to the projects in Afghanistan. [8]

- Lack of capacity

- Lack of professional and skilled project managers

- Lack of project management in institutions curriculum

- Corruption in the government system

- Cost of a project from first contractor up the last one decreases up to (1million falls to 3 hundred thousand)

- Lack of information

- Projects were not prioritized

- Lack of cooperation between the public organizations and private sector

- Lack of coordination between the government and donor countries

- Lack of coordination between government planning and the actual needs of the people

\section{External factors}

As Afghanistan depends on donor aid the external factors had more of an effect on the projects in Afghanistan, and as well there are several other challenging external factors contributing to the project challenges in the country as follows: [8]

- Miscommunications between the donors and project implementers (Private Sector) and the government of Afghanistan

- Dependency of the projects on donor aid

- Donor makes a contract with a company outside the country, then the project goes to second and third subcontracts which cause the quality to decrease

- Government is not allowed to monitor and control the projects which are funded and contracted by the donor countries directly.

- Massive corruption usually in contract phase of project as the first contractor sells the project to another contractor for the implementation.

- Lack of expenditure reports on project implementation by the donor countries to Afghanistan's public sector.

- Government cannot monitor and control projects while implemented by the donor countries, as the donor countries contend that the government of Afghanistan does not have sufficient capacity to monitor and control the projects.

\section{Project Delay in Afghanistan}

A large number of construction projects in Afghanistan has experienced delay. The evaluation reports from different international organizations on Afghanistan's infrastructure projects indicated several factors contributing to project delay in Afghanistan. The assessment reports from the office of Special Inspector General for Afghanistan's Reconstruction (SIGAR), World bank, and Asian Development Bank (ADB) indicated some of the projects that experienced delay in different parts of Afghanistan: [9]

a) SIGAR (2009) pointed out several factors altering the duration of the project; construction of detention facility at a US funded counter narcotics justice centre in Kabul, Afghanistan. The project started in 2007 and finished in 2009, finishing 18 months behind schedule due to several factors including: [10]

- Insufficient funding

- Inadequate electricity

- Scope modification and changes during construction of the project

b) SIGAR (2010a) indicated several factors contributing to project delay in a joint regional Afghanistan national security forces compound (JRAC), 4 projects including regional logistic center (RLC), Afghanistan national civil order police (ANCOP), uniformed police (UP), border police (BP). Projects started in 2008, so the following table describes the projects original completion date based on the contract and actual project completion date, [11] 
Table (1) JRAC 4 projects completion date based on the contract and actual completion date

\begin{tabular}{|c|c|c|}
\hline $\begin{array}{c}\text { Name of the } \\
\text { project }\end{array}$ & $\begin{array}{c}\text { Original } \\
\text { completion date }\end{array}$ & $\begin{array}{c}\text { Actual } \\
\text { completion date }\end{array}$ \\
\hline RLC & Sep 3, 2007 & Oct 22, 2009 \\
\hline ANCOP & Nov 16, 2009 & June 30, 2010 \\
\hline UP & Aug 16, 2009 & March 28, 2010 \\
\hline BP & July 29, 2009 & July 15, 2010 \\
\hline
\end{tabular}

Source: Sigar,2010

The first project RLC experienced almost two years of delay, ANCOP and UP projects experienced 7 months of project delay, and BP project experienced a one-year delay. [11]

Land dispute and project relocation issues, inadequate project planning and oversight contributed to the project lengthy duration. [11]

c) SIGAR (2010b) observed numerous challenges during the implementation of projects: construction of Afghan national police district headquarters facilities in Garm Ser, Nad Ali, and Nahri Saraj district of Helmand and Takhta Pul, Spin Boldak, and Zehellin district of Kandahar province. [12] The project started in May, 2007 and has expected to be completed in January, 2009 but different factors caused the projects to incur delay. The projects were completed on May 2010 with one year and five months of delay. Numerous factors contributed to the project duration such as; contract modification including scope changes, delay in construction due to confusion between project stakeholders on design issues, and delay due to issuance of suspension letter from the client to the contractor due to security issues. [12]

d) SIGAR (2011a) indicated that the project of the construction of Kabul military training centre (KMTC), a training base for newly recruited personnel into the Afghanistan National Army (ANA) experienced delay during the construction. The project started in November 8, 2006 and has expected to be completed in January 20, 2010, but the project was not completed and ultimately the project was completed on Aug 16, 2011 with almost 20 months of delay. Several factors contributed to the project's delay such as: additional work added to the contract, unanticipated site condition, contractor's performance problem, security issues, and inadequate planning of the project. [11]

e) SIGAR (2011b) observed that the construction of Afghan National Security University (ANSU) has faced delay during the implementation. The project started in September 2008 and has expected to be completed in June 2010 but the project was completed in October 2011 with one year and 10 months of delay. There are several factors, which caused the project to experience delay including: scope changes by adding additional work to the scope of the project, waiting for demining the area, project design change, and weakness in contract administration. [12]

f) Since 2001 the GIRoA were unable to provide reliable electricity to a number of big cities in Afghanistan due to numerous factors therefore, the United States funded 5 power projects in different provinces of Afghanistan to provide electricity for the designated areas. SIGAR (2012) observed that the projects including south east power system (SEPS), transmission lines (TLs) and Substations (Ss), SEPS Kandahar city to Durai Junction TL\&Ss, North East Power System (NEPS), Dasht-i-Barchi to Gardez TL\&Ss, Neps Dasht-i-Barchi to Maydan Shahr to Gardez TL\&Ss were not completed on time due to several reasons including: the late arrival of fiscal year 2011 Afghanistan Infrastructure Fund (AIF) funds, project team reorganization, personnel changes, programmatic changes to project execution, and difficulties of field personnel travelling to the proposed project sites to assess projects. [13]

g) SIGAR (2013) observed that the construction of building facilities at the ANP provincial headquarters in Kunduz Province has faced delay during construction. The project started in August 2010,and during the site inspection of SIGAR from the project almost 50 percent of the project was completed, and the project was over one year behind schedule due to unstable soil conditions and sink holes on the project site as well due to weather condition. And as a result, the contractor required modification of the contract leading to the project experiencing delay. [14]

h) In 2010, Asian Development Bank (ADB) reviewed Andkhoy to Qaisar Road project completion report in Afghanistan: the project was supported by ADB and had 3 components, [9]

I. A $55 \mathrm{~km}$ road from Qaisar to Almar,

\section{A $70 \mathrm{~km}$ road from Almar to Shirin Taghab}

III. A $85 \mathrm{~km}$ road from Shirin Taghab to Andkhoy and were constructed by a single contractor.

The projects started in August 2006 and was completed in June 2010. The first component of the project experienced 33 months of delay, the second component experienced 32 months' delay and the third component experienced 20 months of delay.

Numerous factors contributed to the project delay such as:

1. Delays in appointing the supervision consultant due to the withdrawal of the first-rank firm on security concerns.

2. Slow mobilization of equipment and resources by the contractors

3. Design change of vertical alignment in mountainous areas

4. Abnormal rains and flash flooding from March to May 2009

5. The Afghan presidential election in 2009

6. Numerous security incidents

7. MOPW's weak management capacity and supervision consultant's slow actions that led to lengthy negotiations with the contractors and prolonged processing and 
approval of extra work variation claims.

i) The World bank provided a grant under the program of the Afghanistan Reconstruction Trust Fund (ARTF) for Kabul Aybak Mazar-e-Sharif power project (World bank, 2012). [9] The project aimed to provide reliable and quality power in the target areas of the cities of Kabul, Aybak and Mazar-e-Sharif. The project had four components: [9]

1: Distribution system for the rehabilitation of Kabul electricity

2: Establishment of a new 220/20 kV substation at Aybak and inter- connection with the distribution system;

3: Rehabilitation of the Mazar-e-Sharif power system

4: Institutional capacity building and support

The duration of the project was from December 26, 2007 to December 31, 2009. The project was not completed on time and due to numerous factors 39 months of delay occurred to the project and the project was supposed to be completed on March 31, 2013.

The World bank demonstrated that the project as a whole has suffered significant delays due to:

- Weak capacity, particularly for project management, which has been addressed by extensive reliance on supervision consultants.

- Demobilization of the previous project management firm (PMF) resulted in a considerable slowdown in physical progress on site.

- Delays in payments to contractors and progress reporting.

- The arrival of goods has been delayed by slow issuance of duty exemption certificates and so goods have not been released by customs.

- Poor Cooperation between DABS and MEW,

- Insufficient packing of containers

- Poor road condition

- Security challenges

j) U.S. Agency for International Development (USAID) provided fund for the construction of a 105-megawatt power plant on the outskirts of Kabul. SIGAR (2010c) pointed out that the project started in July 2007 and was scheduled for completion on March 31, 2009, but the project was not completed on time and due to several factors 12 months' delay occurred and finally the project was completed on March 31, 2010. The factors contributed to the project delay include: [15]

- An initial inability to obtain adequate title to land for construction

- USAID's inclusion of an ambiguous statement of work resulting in poor planning and implementation

- Contractors delays in subcontractor awards and mobilization

- Subcontractor performance problems related to generator delivery delays and an inability to find enough qualified workers to keep the project on schedule

- Lack of on-site quality assurance
- Delays in getting timely approvals from USAID's contracting officer

- Poor communication between USAID and the project contractor

- Transportation and customs clearance problems

\section{Causes of Project Delay in the Construction Industry in Afghanistan}

Conducted a case study entitled causes of project delay in the construction industry in Afghanistan. Data was collected through questionnaire from 3 points of view, Client or the owner of the project, Consultant and Contractor. The findings of the study revealed the top 10 significant factors causing delay in the construction industry of Afghanistan as fallowing: [16]

\section{Security}

2. Corruption

3. Poor qualification of the contractor's technical staff

4. Delay in progress payments by owner

5. Poor site management and supervision by contractor

6. Ineffective planning and scheduling of project by contractor

7. Type of project bidding and award (negotiation, lowest price and etc.)

8. Difficulties in financing project by contractor

9. Poor communication and coordination by contractor with other parties

10. Frequent change of subcontractors because of their inefficient work

\section{Materials \& Methods}

The methodology of this research is based on qualitative and quantitative data collection methods. The qualitative data is collected through review of books, observations, interviews and review of other scholars' papers concerning similar research in developing countries such as India, Malaysia, Tanzania, Nigeria, Ghana.

Literature was reviewed to find out the observation of other scholars concerning projects delay. Initially similar research has been reviewed and as well findings from the project management challenges are pointed out, and then from the aforementioned studies reviews, the questionnaire has been formulated with 30 factors; these factors were selected based on their frequency, which have high potential of occurrence in Afghanistan. Furthermore, these factors were selected based on the frequency of occurrence in developing countries.

\section{Data Collection}

For the purpose of data collection, the questionnaires have been distributed to those organizations of the Afghanistan's government that are mainly involved in infrastructure projects in all around the country. 50 questionnaires have been distributed to the related Ministries (MRRD, MOUDA, MOE, MOPW,

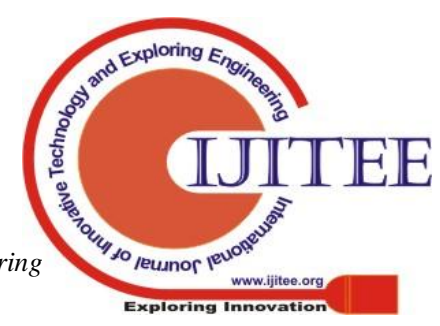


and MEW) of the Afghanistan's government and 30 out of 50 questionnaires, which shows $60 \%$ of response rate here, returned and properly filled out for the purpose analysis. For the distribution of the questionnaire the researcher personally visited each organization and in some cases the questionnaires have been collected through emails from some officials. The period of data collection through questionnaire was between March15, 2017 and September 14, 2018.

Regarding the ranking of the officials responding to the questionnaire, around 40 percent of respondents are first and second rank officials which are mainly director generals and directors in the government of Afghanistan, and the remaining 60 percent are project employees such as project manager, deputy project managers, project engineers, site engineers, project inspectors and so on. And the distributions of respondents are as follows:

10 respondents from MEW, 9 respondents from the MOPW, 6 respondents from MRRD, 3 respondents from MOUDA, and the final 2 respondents from MOEC. The following table sheds light on the number and percentage of respondents from 5 different organizations of Afghanistan.

Table (2) response rate based on the organizations

\begin{tabular}{|c|c|c|}
\hline Organization & $\begin{array}{c}\text { Number of } \\
\text { respondents }\end{array}$ & $\begin{array}{c}\text { Percentage of } \\
\text { respondents }\end{array}$ \\
\hline MEW & 10 & 33.33 \\
\hline MOPW & 9 & 30 \\
\hline MRRD & 6 & 20 \\
\hline MOUDA & 3 & 10 \\
\hline MOEC & 2 & 6.67 \\
\hline Total & $\mathbf{3 0}$ & $\mathbf{1 0 0 \%}$ \\
\hline
\end{tabular}

Source: Survey conducted by the researcher

\section{Data Analysis}

For analysing the calculated data, the relative important index (RII) method is used. The (RII) is full form of Relative Importance Index Technique [Tam and Le,2006]:

It is used determine the relative importance of the various causes and effects of delays. The four-point scale ranged from 1 (Not important) to 4 (very important) is calculated as follow:

$\mathrm{RII}=\Sigma \mathrm{W} / \mathrm{A} * \mathrm{~N}$

Where; $\mathrm{W}=$ weight given to each factor by respondents

$\mathrm{A}=$ highest weight

$\mathrm{N}=$ total number of respondents.

For the purpose of this study $\mathrm{A}=4$ and $\mathrm{N}=30 .(0.25 \leq \mathrm{RII} \leq 1)$ and calculated in Microsoft excel sheet. Based on the responded questionnaires top 10 factors need to be identifiedthe following table describes the analysis of the project delay based on the collected data from different public organizations of Afghanistan, which is sorted based on the RII.

Table (3) Data analysis of project delay based onthe calculated data

\begin{tabular}{|c|c|c|c|c|c|c|}
\hline Causes of project delay & $\begin{array}{l}\text { Very } \\
\text { Import } \\
\text { ant }\end{array}$ & $\begin{array}{l}\text { Impo } \\
\text { rtant }\end{array}$ & $\begin{array}{l}\text { Less } \\
\text { Impo } \\
\text { rtant }\end{array}$ & $\begin{array}{l}\text { Not } \\
\text { Impo } \\
\text { rtant }\end{array}$ & RII & $\begin{array}{l}\mathrm{Ra} \\
\mathrm{nk} \\
\mathrm{S}\end{array}$ \\
\hline $\begin{array}{l}\text { Ineffective planning and } \\
\text { scheduling of project by } \\
\text { contractor }\end{array}$ & 17 & 10 & 3 & 0 & 0.866666667 & 1 \\
\hline $\begin{array}{l}\text { Delay in progress } \\
\text { payments by client }\end{array}$ & 14 & 15 & 1 & 0 & 0.858333333 & 2 \\
\hline $\begin{array}{l}\text { Poor site management } \\
\text { and supervision of } \\
\text { contractors by } \\
\text { consultant and client }\end{array}$ & 14 & 13 & 3 & 0 & 0.841666667 & 3 \\
\hline $\begin{array}{l}\text { Financial difficulties by } \\
\text { contractor }\end{array}$ & 12 & 13 & 5 & 0 & 0.808333333 & 4 \\
\hline $\begin{array}{l}\text { Insufficient controlling } \\
\text { and monitoring by } \\
\text { consultant and client }\end{array}$ & 11 & 15 & 4 & 0 & 0.808333333 & 4 \\
\hline $\begin{array}{l}\text { Non availability of } \\
\text { experienced technical } \\
\text { staff of contractor }\end{array}$ & 8 & 19 & 2 & 1 & 0.783333333 & 6 \\
\hline $\begin{array}{l}\text { Late in reviewing and } \\
\text { approving design } \\
\text { documents by client }\end{array}$ & 7 & 18 & 5 & 0 & 0.766666667 & 7 \\
\hline $\begin{array}{l}\text { Lack of communication } \\
\text { and coordination } \\
\text { between the parties }\end{array}$ & 9 & 14 & 6 & 1 & 0.758333333 & 8 \\
\hline $\begin{array}{l}\text { Delay in delivery of } \\
\text { materials to site }\end{array}$ & 6 & 19 & 5 & 0 & $\begin{array}{l}0.75833333 \\
3 \\
\end{array}$ & 8 \\
\hline $\begin{array}{l}\text { Inadequate contractor } \\
\text { experience }\end{array}$ & 7 & 17 & 5 & 1 & 0.75 & 10 \\
\hline $\begin{array}{l}\text { Political influences and } \\
\text { warlord intervention }\end{array}$ & 7 & 18 & 3 & 2 & 0.75 & 10 \\
\hline $\begin{array}{l}\text { Scope changes by client } \\
\text { during construction }\end{array}$ & 4 & 21 & 5 & 0 & $\begin{array}{l}0.74166666 \\
7\end{array}$ & 12 \\
\hline $\begin{array}{l}\text { Long waiting time for } \\
\text { approval of tests and } \\
\text { inspection by } \\
\text { consultant }\end{array}$ & 8 & 13 & 9 & 0 & $\begin{array}{l}0.741666666 \\
7\end{array}$ & 12 \\
\hline $\begin{array}{l}\text { Late procurement of } \\
\text { materials }\end{array}$ & 7 & 15 & 8 & 0 & $\begin{array}{l}0.74166666 \\
7\end{array}$ & 12 \\
\hline $\begin{array}{l}\text { Lack of incentives for } \\
\text { contractor to finish } \\
\text { ahead of schedule }\end{array}$ & 10 & 11 & 6 & 3 & $\begin{array}{l}0.73333333 \\
3\end{array}$ & 15 \\
\hline $\begin{array}{l}\text { Slowness in decision } \\
\text { making process by } \\
\text { client }\end{array}$ & 1 & 24 & 5 & 0 & $\begin{array}{l}0.71666666 \\
7\end{array}$ & 16 \\
\hline $\begin{array}{l}\text { Impractical allocation of } \\
\text { resources }\end{array}$ & 4 & 15 & 10 & 1 & $\begin{array}{l}0.68333333 \\
3\end{array}$ & 17 \\
\hline $\begin{array}{l}\text { Low productivity level } \\
\text { of labors }\end{array}$ & 2 & 19 & 7 & 2 & 0.675 & 18 \\
\hline $\begin{array}{l}\text { Shortage of materials in } \\
\text { the market }\end{array}$ & 5 & 10 & 15 & 0 & $\begin{array}{l}0.66666666 \\
7\end{array}$ & 19 \\
\hline $\begin{array}{l}\text { Low motivation and } \\
\text { morale of labor }\end{array}$ & 2 & 17 & 9 & 2 & $\begin{array}{l}0.65833333 \\
3\end{array}$ & 20 \\
\hline $\begin{array}{l}\text { Unrealistic contract } \\
\text { duration }\end{array}$ & 6 & 10 & 11 & 3 & $\begin{array}{l}0.65833333 \\
3\end{array}$ & 20 \\
\hline $\begin{array}{l}\text { Unclear and inadequate } \\
\text { details in drawings }\end{array}$ & 3 & 12 & 15 & 0 & 0.65 & 22 \\
\hline $\begin{array}{l}\text { Changes in materials } \\
\text { types and specifications } \\
\text { during construction }\end{array}$ & 2 & 16 & 9 & 3 & $\begin{array}{l}0.64166666 \\
7\end{array}$ & 23 \\
\hline $\begin{array}{l}\text { Problems with } \\
\text { subcontractors }\end{array}$ & 4 & 10 & 14 & 2 & $\begin{array}{l}0.63333333 \\
3 \\
\end{array}$ & 24 \\
\hline Unreliable suppliers & 3 & 11 & 15 & 1 & $\begin{array}{l}0.63333333 \\
3 \\
\end{array}$ & 24 \\
\hline $\begin{array}{l}\text { Controlling } \\
\text { subcontractors by main } \\
\text { contractor in the } \\
\text { execution of work }\end{array}$ & 4 & 11 & 10 & 5 & $\begin{array}{l}0.61666666 \\
7\end{array}$ & 26 \\
\hline $\begin{array}{l}\text { Rework due to the } \\
\text { Mistakes during } \\
\text { construction stages }\end{array}$ & 5 & 5 & 18 & 2 & $\begin{array}{l}0.60833333 \\
3\end{array}$ & 27 \\
\hline $\begin{array}{l}\text { Materials price changes } \\
\text { due to the currency } \\
\text { fluctuation }\end{array}$ & 2 & 12 & 13 & 3 & $\begin{array}{l}0.60833333 \\
3\end{array}$ & 27 \\
\hline $\begin{array}{l}\text { Excessive bureaucracy } \\
\text { in project owner } \\
\text { operation }\end{array}$ & 2 & 9 & 16 & 3 & $\begin{array}{l}0.58333333 \\
3\end{array}$ & 29 \\
\hline $\begin{array}{l}\text { Contractors with } \\
\text { political clout }\end{array}$ & 4 & 8 & 11 & 7 & 0.575 & 30 \\
\hline
\end{tabular}

Source: Table is designed based on the survey conducted by the researcher.

Based on the calculation of relative important index in table 5.2, top 10 factor is observable with the highest (RII) of 0.866666667 and lowest of 0.75 , and as the RII of number 11 is same with top 10 , then it is necessary to consider top 11 factors altering projects delay in construction 
projects of Afghanistan. And finally narrowing down to the following table, which describes the top 11 factors, that causes projects delay in construction projects in Afghanistan.

Table (4) Significant factors of delay

\begin{tabular}{|l|l|l|}
\hline $\begin{array}{l}\text { Causes of project } \\
\text { delay }\end{array}$ & RII & Ranks \\
\hline $\begin{array}{l}\text { Ineffective planning and } \\
\text { scheduling of a project } \\
\text { by contractor }\end{array}$ & 0.866666667 & 1 \\
\hline $\begin{array}{l}\text { Delay in progress } \\
\text { payments by client }\end{array}$ & 0.858333333 & 2 \\
\hline $\begin{array}{l}\text { Poor site management } \\
\text { and supervision of } \\
\text { contractors by } \\
\text { consultant and client }\end{array}$ & 0.841666667 & 3 \\
\hline $\begin{array}{l}\text { Financial difficulties by } \\
\text { contractor }\end{array}$ & 0.808333333 & 4 \\
\hline $\begin{array}{l}\text { Insufficient controlling } \\
\text { and monitoring by } \\
\text { consultant and client }\end{array}$ & 0.808333333 & 4 \\
\hline $\begin{array}{l}\text { Non availability of } \\
\text { experienced technical } \\
\text { staff of contractor }\end{array}$ & 0.783333333 & 6 \\
\hline $\begin{array}{l}\text { Late in reviewing and } \\
\text { approving design } \\
\text { documents by client }\end{array}$ & 0.766666667 & 7 \\
\hline $\begin{array}{l}\text { Lack of communication } \\
\text { and coordination } \\
\text { between the parties }\end{array}$ & 0.758333333 & 8 \\
\hline $\begin{array}{l}\text { Delay in delivery of } \\
\text { materials to site }\end{array}$ & 0.758333333 & 8 \\
\hline $\begin{array}{l}\text { Inadequate contractor } \\
\text { experience } \\
\text { warlord's intervention }\end{array}$ & 0.75 & 10 \\
\hline
\end{tabular}

Source: result of the conducted survey by the researcher

\section{RESULTS AND DISCUSSIONS}

Based on the analysis of the collected data, the researcher deliberates the top 11 factors, which are causing delay in construction projects in Afghanistan.

\section{Ineffective planning and scheduling of project by} contractor:

This factor has the highest influence to the project's duration with the RII of 0.866666667.

As it is clear; Afghanistan is a country, which has suffered for almost 4 decades of war andinsurgency, and as a result the people have been deprived of proper education and knowledge in different aspects of life, especially the education system remained very archaic and could not fulfill the requirements of modern life. People educated from these old system institutions are being hired by the contractors; So most domestic contractors do not have proper skills of managing projects activities therefore, these contactors have less experience and knowledge about project planning and scheduling, this factor primarily causes delay in the projects.

\section{Delay in progress payments by client}

In this study, ministries in the government of Afghanistan as clients of the construction projects in the country are responsible to make payments to the contractors on time, based on the executed work by contractors, but due to several problems delay occurs in payment of the liquidation to the contractors.

Normally based on the procurement policy, when a government body signs a project contract with a contractor, the government body as the client of the project is required to pay some percentage of the overall contract amount to the contractor for mobilization purposes so the contractor could start the project, then based on the executed work, the rest of the project funds would be released by the client to the contractor based on their performanceand completed work.

The required amount of the money for mobilization purposes should be handed over to the contractors sometime after the contract is signed with the contractor through Ministry of Finance, but as the prolonged procedure of the payments by the client which is very lengthy and usually it takes months, causing project delay even before a project kicks off.

Another problem is the financial disbursement during the projects progress stages. It happens when the contractor accomplishes a certain amount of work and request payment for the executed work. Then ministry as client issues a certificate based on the supervision of the project manager from the projects. The project manager and other technical staff visits the project and confirms the amount of completed work and then they issue the certificate, which usually takes time for the supervision and certificate issuing purpose. Then based on the certificate the Ministry of Finance releases a certain amount of money to the contractor and it takes longer time to release the money. the prolonged procedure of payments by the government and time-consuming supervision of the project manager and other technical officials from the projects takes time and causes the contractors to face a lack of liquidation during project implementation and in some cases the contractor stops the work because they are not paid in a reasonable time.

\section{Poor site management and supervision of contractors by consultant and client}

The donor countries require the government bodies to hire consultants to supervise the overall activities of the contractors and report it to the donor agencies. Due to several factors in the government of Afghanistan, the government does not have much ability and personnel to supervise work progress of the projects. Therefore, the government hires consultants to directly supervise the projects and report to the government, but in some cases the consultant as supervisor of the projects are not going to site for the supervision due to some reason or another

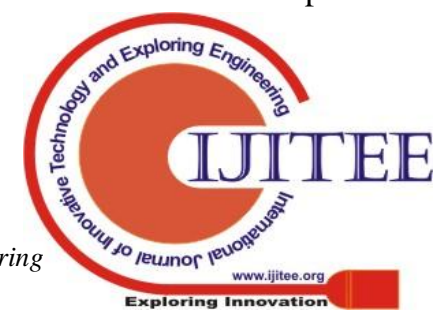


and causes poor site management and poor supervision of the projects.

For most of the infrastructure projects, the government is directly supervising the overall activates of the contractors, and for this purpose the government hires a project manager with a project facilitator such as administrator and finance assistant to supervise the project and report the progress of work to the government authorities. As the government is unable to pay high wages to the officials, professional and skilled personnel are not willing to work in the government sector due to the low wages. So, most of the government official capacities are low and they don't have much experience in projects supervision and site management, causing projects delay. There are also some other factors such as corruption in the whole system of the government which are influencing poor site management and supervision of the projects in the government of Afghanistan.

\section{Financial difficulties by contractor}

Most of the contractors of the construction projects are local contractors and they do not have financial capability to complete a project with their own cash so mainly they depend on the client's money. In this case when a certain amount of work is completed, the contractor requests the client to make payment of the executed work. So, if the client could not make disbursement, then the contractor will not be able to continue the projects work until they are paid, so it causes delay.

\section{Insufficient controlling and monitoring by consultant and client}

The Government of Afghanistan as client mostly lacks experts and professionals of project management. The people who get experience and becomes professional in the government is leaving from the government sector, because government is unable to pay enough wages to fulfil the needs of the daily life of its employees. Mainly officials remaining in the government sector have less capacity to sufficiently monitor and control the overall activities of the projects, However, Foreign consultants are good at monitoring and controlling over the activities of the projects but in some cases when they face problem in monitoring and controlling, it causes delay.

\section{Non availability of experienced technical staff of contractor}

Most contractors are domestic organizations, and in generally the country is lacking expertise in different sectors. The technical field is also a major area in which there is less experienced staff working in the organization which are undertaking the infrastructure projects. If there is less technical staff or unavailable technical staff in an organization contracting the infrastructure project, they will definitely face problem in different stages of projects implementation and it takes time to overcome those problems which causes delay in the projects.

\section{Slow in reviewing and approving design documents} byclient

Project managers in the Government of Afghanistan as client is required to approve design documents prior to the start of a project. As there is less qualified and few professionals working in the government, they are taking much time to review and approve the design documents of the projects, therefore delay occurs.

\section{Lack of communication and coordination between the parties}

Although there have been efforts for e-Government in Afghanistan, most of the communication between the projects stakeholders is paper-based. The contractor is reporting the progress of the work through memos and documents and paper-based communication is time consuming, and moreover most of the officials in the government have less capacity and knowledge of project management.

Coordination between the parties are mainly based on their communication. If communication is weak then most probably there is less coordination. However, communication is a key to successful project delivery.

\section{Delay in delivery of materials to site}

Contractors mostly imports materials from the neighbouring countries for the projects, and custom clearance issues are increasing time to import the goods and in some cases, due to the political situation with the neighbouring countries, the materials are being detained at the border until the situation improves and the contractor gets the goods and delivers to the site. Furthermore, roads are not well constructed and also there is lack of highways to the projects. So, due to aforementioned reasons, delay occurs.

\section{Inadequate contractor experience}

Most of the contractors of the construction projects for the government of Afghanistan are local contractors with less experience and less qualified people. As Afghanistan continues to recover from the war, international contractors are not willing to implement the infrastructure projects in the countryside, so government have only one choice but to implement the projects by the domestic contractors even though they have less experience and less technical personals.

\section{Political influences and warlord intervention}

Some of the warlords became politicians through democratic elections, and they are directly or indirectly influencing the projects work. Usually they intervene in projects activities, which are being implemented in their home province or district. In some cases, they take kickbacks from the contractors. Most of the warlords are active in their home territory and are causing loss to the contractors by demanding bribes, and in some cases even warlords force the contractors to hire their people for the projects.

\section{CONCLUSION}

\& Sciences Publication 
A large number of Public Construction projects in Afghanistan are not implemented on time; due to several factors delay arises, so the construction projects fail to meet their contract time and project delay negatively impacts the development process of the country. The impact of project failure in Afghanistan negatively affects the prestige and dignity of the government organizations. Some of the project failures caused the destruction of hope of the people. Since the Afghanistan government depends on donor aid, the factors of delay mainly affect the contribution of the donor agencies in the country. Due to simultaneous occurrences of the delay in development projects funded by donors in Afghanistan, it would minimize their contribution to the development projects. In general, failures and flaws of the projects created distance between the people and the government and shows the weakness of the government in the implementation of the projects all over the country in Afghanistan. As human living quality depends on the implementation of infrastructure projects in a country, so the aim of this research is to find out projects delay factors and mainly the significant causes of delay in construction projects in Afghanistan and to recommend appropriate solutions to avoid delay in construction projects in Afghanistan.

\section{REFERENCES}

1. Asian Development Bank (ADB) completion report. (2010). Afghanistan: Andkhoy-Qaisar Road Project.

2. Retrieved May 12, 2016, Special Inspector General for Afghanistan Reconstruction (SIGAR). (2011a). Better Planning and Oversight Could Have Reduced Construction Delays and Costs at the Kabul Military Training Center. SIGAR Audit-12-2

3. Special Inspector General for Afghanistan Reconstruction (SIGAR) (2011b). Afghan National Security University Has Experienced Cost Growth and Schedule Delays, and Contract Administration Needs Improvement. SIGAR Audit-12-3.

4. Special Inspector General for Afghanistan Reconstruction (SIGAR). (2012). Fiscal Year 2011 Afghanistan Infrastructure Fund Projects Are behind Schedule and Lack Adequate Sustainment Plans. SIGAR Audit-12-12.

5. David, M., \& Ore, K.J. (2010). Business Q\&A, what major challenges have you observed with completing construction projects in Afghanistan. Retrieved April 25, 2015

6.Sadeqi, H. (2014). The main challenges of development projects in Afghanistan. Retrieved August 18, 2015.

7. Barmak, W. (2013). Main challenges of National Solidarity projects in Afghanistan. Retrieved June 2015.

8.Nushin, W. (2012). Factors which are Causing Projects Failure in Afghanistan [Web log post].

9.The World Bank. (2012). Restructuring Paper on a Proposed Project Restructuring of Afghanistan Kabul Aybak Mazar e Sharif Power Project.

10.Special Inspector General for Afghanistan Reconstruction (SIGAR) (2009). Actions needed to resolve construction delays at the counter-narcotics justice centre. SIGAR Audit-09-4.

11.Retrieved Special Inspector General for Afghanistan Reconstruction (SIGAR). (2011a). Better Planning and Oversight Could Have Reduced SIGAR Audit-12-2. Retrieved May 12, 2016

12.Special Inspector General for Afghanistan Reconstruction (SIGAR). (2010b). ANP District Headquarters Facilities in Helmand and Kandahar Oversight and Poor Contractor Performance. SIGAR Audit-11-3.

13. Special Inspector General for Afghanistan Reconstruction (SIGAR). (2012c). Fiscal Year 2011 Afghanistan Infrastructure Fund Projects Are behind Schedule and Lack Adequate Sustainment Plans. SIGAR Audit-12-12. Retrieved May 12, 2016.

14. Special Inspector General for Afghanistan Reconstruction (SIGAR). (2013). Knduz Afghan National Police Provincial Headquarters: After Construction Delays and Cost Increases, Concerns Remain About the Retrieved May 12, 2015. Construction Delays and Costs at the Kabul Military Training Center. Provinces Have Significant Construction Deficiencies Due to Lack of Facilities Usability and Sustainability. SIGAR Inspection-13-4.

15. Special Inspector General for Afghanistan Reconstruction (SIGAR), (2010c).

16.Significant Factors Causing Cost Overruns in the Construction Industry in Afghanistan By: Ghulam Abbas Niazia, *, Noel Paintingb.2017.

\begin{tabular}{|c|c|}
\hline $\mathrm{ADB}$ & $\begin{array}{l}\text { Abbreviations } \\
\text { Asian Development Bank }\end{array}$ \\
\hline AIF & Afghanistan Infrastructure Fund \\
\hline ANA & Afghan National Army \\
\hline ANSU & Afghan National Security University \\
\hline ARTF & Afghanistan Reconstruction Trust Fund \\
\hline DABS & Da Afghanistan Breshna Sherkat \\
\hline
\end{tabular}

GoIRA Government of the Islamic republic of Afghanistan

KMTC Kabul Military Training Centre

KV Kilovolt

MEW Ministry of Energy and Water

MOEC Ministry of Economy

MOF Ministry of Finance

MOPW Ministry of Public Works

MOUDA Ministry of Urban Development Affairs

MRRD Ministry of Rural Rehabilitation and Development

NEPS North East Power Systems

NGO Non-Governmental Organization

PMBOK Project Management Body of Knowledge

PMF Project Management Firm

PMI Project Management Institute

RII Relative Important Index

SEPS South East Power System

SIGAR Special Inspector General for Afghanistan Reconstruction

Ss Substations

TL Transmission Line

UNDP United Nations Development Program

USAID United States Agency for International Development

WBS Work Breakdown Structure

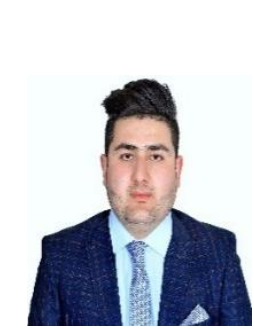

\section{AUTHORS PROFILE}

Sayed Behbood Hosaini is a candidate of $\mathrm{PhD}$ in Construction \& Maintenance Management, RIMT University-India. He did Master of Structural Engineering from Kabul Polytechnic University,2018 and Bachelor of Civil Engineering, Dawat Kabul Unversity,2012.His professional Experience included Outreach Urban Infrastructure Specialist at Europe Union Project for Supporting of Herat Municipality from 16 Dec 2018 till present, Deputy of Khawf - Herat Railway Project in Afghanistan Railway Authority (ARA) from 21 Dec 2016 at 15/Dec/2018, Safety - Customs - Transit- Loading \& Unloading Manager in Afghanistan Railway Authority (ARA), Ministry of Public works, Kabul-Afghanistan, from 20 Sep 2014 at 20 Dec 2016Quality Control Manager in Maqsood Rahmani Construction Company (MRCC), Kabul-Afghanistan. From 15 Jan 2013 at 30 August 2014 and Intern Design and Construction Engineer in Road and Roof Construction Company (RRCC), Kabul- Afghanistan from 08 March 2012 - 10 January 2013. 


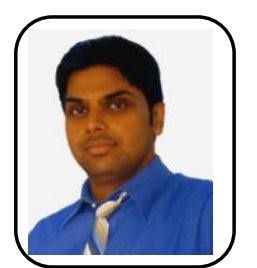

DR SANDEEP SINGLA received his B.Tech degree in civil engineering in 2001 from Punjab Technical University, JalandharM.Tech from Thapar Institute of Engineering \& Technology, Patiala in $2004 \& \mathrm{PhD}$ degree from National Institute of echnology (NIT) Kurukshetra in 2018. Presently, he is working as Professor \& Head in Department of Civil Engineering, RIMT University, Punjab, India. He has published more than 60 papers in national and international journals/conferences. He has guided more than $30 \mathrm{M}$.Tech thesis. Besides being member of board of studies in various universities, he is a life member of ISTE and also member of IEI. His research interests include environmental engineering, waste management, concrete technology, artificial intelligence, remote sensing and GIS. 